\title{
Antigenic characterisation of a novel Streptococcus anginosus antigen that induces nitric oxide synthesis by murine peritoneal exudate cells
}

\author{
M. SASAKI, Y. OHARA-NEMOTO, S. TAJIKA, M. KOBAYASHI, C. YAMAURA and S. KIMURA \\ Department of Oral Microbiology, Iwate Medical University School of Dentistry, Morioka, Iwate, Japan
}

\begin{abstract}
A novel antigen that induces nitric oxide (NO) synthesis by murine peritoneal exudate cells (PEC) was prepared from a culture supernate of Streptococcus anginosus NCTC 10713 in dialysed medium by column chromatography with DEAE-Sephacel followed by size-exclusion high performance liquid chromatography (HPLC). A chemical analysis of the $S$. anginosus antigen (SAA) revealed that it mainly consisted of carbohydrates (rhamnose, $\mathrm{N}$-acetylglucosamine, glucose and galactose), smaller quantities of protein and a trace amount of phosphorus. The SAA stimulated PEC from C57BL/6N mice to produce NO and accumulate induced NO synthetase (iNOS) mRNA in a dose-dependent manner, reaching a plateau with $10-30 \mu \mathrm{g} / \mathrm{ml}$. Furthermore, a reverse transcriptionPCR assay revealed that SAA $10 \mu \mathrm{g} / \mathrm{ml}$ could induce mRNA accumulation of tumour necrosis factor- $\alpha$, interleukin (IL)-1 $\beta$ and IL-6 as well as iNOS. In contrast, RantzRandall antigen (RRA), a carbohydrate antigen prepared from the organisms, could not induce NO synthesis or cause the accumulation of iNOS mRNA, although cytokine production was observed after stimulation. The SAA-induced NO synthesis, but not the cytokine production, was sensitive to heat. Furthermore, an immunoblot analysis of SAA indicated that the $43-\mathrm{kDa}$ protein band reacted with anti-SAA but not anti-RRA antibodies. In immunodiffusion, SAA reacted with both anti-SAA and anti-RRA antibodies, and the precipitin bands formed crossing lines, suggesting that SAA could possess two different antigenic components - one that reacts specificially with anti-SAA antibodies and another that has an identity similar to that of RRA. Taken together, SAA, a novel antigen of $S$. anginosus, was found to induce NO synthesis as well as produce inflammatory cytokines in murine PEC. It is suggested that the protein molecule of SAA may exclusively induce NO synthesis, and its carbohydrate component(s) could have a relationship to cytokine production.
\end{abstract}

\section{Introduction}

Streptococcus anginosus, one of the oral viridans streptococci, is a common commensal organism found in the human oral cavity and on other mucosal surfaces, such as the upper respiratory and gastrointestinal tracts. This organism is generally considered to have a low pathogenicity; however, it can cause serious purulent abscesses in various body sites [1-3] and subacute bacterial endocarditis $[1,4]$. Despite its recently increased clinical significance, little is known about the pathogenic mechanisms of $S$. anginosus and

Received 29 Dec. 2000; revised version accepted 22 May 2001.

Corresponding author: Dr S. Kimura (e-mail: kimuras@ iwate-med.ac.jp). the specific factors for its activities remain to be elucidated.

Several components of the oral streptococcal cell wall including peptidoglycans, lipoteichoic acids, surface proteins and carbohydrate antigens, can trigger macrophages to induce cytokines, such as tumour necrosis factor (TNF)- $\alpha$, and interleukin (IL)-1 and IL-6, that are involved in inflammatory and immunological reactions in the host [5-9]. Furthermore, some cell wall components from oral viridans streptococci have been shown to induce the production of nitric oxide (NO) from murine macrophages; e.g., serotype polyosides (rhamnose glucose polymers, RGPs) from $S$. mutans [10] and lipoteichoic acid (LTA) from $S$. sanguis and $S$. mutans [11]. Although NO has been implicated in macrophage-mediated cytotoxicity against various pathogens and may play a role in persistent or latent 
infections, its overproduction, induced by such bacterial components as lipopolysaccharide (LPS) and LTA, could cause damage to host tissues or induce circulatory failure in gram-positive septic shock, or both [12].

The present study examined the induction of production of NO as well as inflammatory cytokines from murine peritoneal exudate cells (PEC) by a novel antigen purified from the culture supernate of $S$. anginosus (SAA).

\section{Materials and methods}

\section{Preparation of SAA and biological standards}

S. anginosus NCTC 10713 (Lancefield group G) was cultured in dialysed Todd Hewitt Broth (BBL Microbiology Systems, Cockeysville, MD, USA) at $37^{\circ} \mathrm{C}$ for $24 \mathrm{~h}$. The supernate was collected by centrifugation and filtered through a $0.45-\mu \mathrm{m}$ membrane. The supernate was then applied to a DEAE-Sephacel column (Amersham Pharmacia Bioteck, Uppsala, Sweden) and washed with $20 \mathrm{mM}$ Tris- $\mathrm{HCl}$ buffer at $\mathrm{pH}$ 8.0. The absorbed fractions were eluted with a linear gradient of $0-0.5 \mathrm{M}$ $\mathrm{NaCl}$ in the same buffer. The fractions showing NOinducing activity were combined, and then concentrated by ultrafiltration with a YM-10 membrane (Amicon, Beverly, MA, USA). The concentrated fraction was further subjected to size-exclusion high-performance liquid chromatography (HPLC) with a TSK gel G4000 column (Tosoh, Tokyo, Japan) equilibrated with $20 \mathrm{mM}$ Tris- $\mathrm{HCl}$ buffer at $\mathrm{pH}$ 8.0. The eluted fraction was designated as SAA. In some experiments, heat-treated $\left(121^{\circ} \mathrm{C}\right.$ for $\left.20 \mathrm{~min}\right) \mathrm{SAA}$ was used.

The Rantz-Randall antigen, a carbohydrate antigen, was prepared from S. anginosus NCTC 10713 as described by Hamada et al. [13]. Briefly, S. anginosus whole cells $50 \mathrm{mg} / \mathrm{ml}$ in sterile saline were autoclaved at $121^{\circ} \mathrm{C}$ for $20 \mathrm{~min}$ and the centrifuged supernate (RRA) was collected. The LPS used in this study was prepared by further purification from a commercial preparation of LPS from Escherichia coli O128:B12 (Sigma) by the phenol-water extraction method. Purified LTA from S. sanguis was purchased from Sigma.

\section{Chemical analysis of SAA}

Total hexose was quantified by the phenol-sulphuric acid method [14] and rhamnose, glucose, galactose and hexosamine ( $N$-acetylglucosamine and $N$-acetylgalactosamine) by the colorimetric method [15-18]. The protein and phosphorus contents of SAA were measured by the methods of Bradford [19] and Chen et al. [20], respectively.

\section{$N O$ and TNF- $\alpha$ production}

PEC were collected by lavage from $\mathrm{C} 57 \mathrm{BL} / 6 \mathrm{~N}$ mice $(8$ weeks old; CLEA Japan, Osaka, Japan) that had been given $1 \mathrm{ml}$ of Thioglycolate Medium (Nissuii, Tokyo, Japan) by intraperitoneal injection as described previously [21]. The PEC were resuspended at $5 \times$ $10^{5}$ cells $/ \mathrm{ml}$ in sterile RPMI 1640 medium (Sigma) supplemented with gentamicin (Sigma) $50 \mu \mathrm{g} / \mathrm{ml}$ and heat-inactivated fetal calf serum (FCS; ICN Biomedicals Japan, Osaka, Japan) $10 \% \mathrm{v} / \mathrm{v}$, and cultured with SAA or the biological standards in triplicate at $37^{\circ} \mathrm{C}$ in humidified $\mathrm{CO}_{2} 5 \%$ in air. After incubation for $24 \mathrm{~h}$, the NO content of the culture supernates was estimated by an analysis of nitrite (production of rapid oxidation of NO in aqueous solution) with Griess reagent [22]. The TNF- $\alpha$ concentration in the culture supernates was measured with a mouse TNF- $\alpha$ ELISA kit (R\&D System, Minneapolis, MN, USA), according to the manufacturer's instructions.

\section{RT-PCR analysis}

The expressions of induced NO synthetase (iNOS), TNF- $\alpha$, IL- $1 \beta$ and IL-6 specific mRNA in SAAstimulated PEC were examined by reverse transcriptase (RT)-PCR. RT-PCR was performed essentially as reported previously $[9,23]$. Briefly, RNA was purified by the acid guanidinium thiocyanate-phenol-chloroform extraction procedure with TRIzol Reagent (GIBCO-BRL, Gaithersburg, MD, USA). The RNA was reverse transcribed into cDNA in a reverse transcription mixture consisting of a first strand buffer (50 mM Tris- $\mathrm{HCl}, \mathrm{pH} 8.3 ; 75 \mathrm{mM} \mathrm{KCl} ; 3 \mathrm{mM} \mathrm{MgCl}_{2}$ ), $1 \mathrm{mM}$ dNTP, 10 units of RNAase inhibitor (RNasin; Promega, Madison, WI, USA), $4 \mu \mathrm{M}$ oligo(dT) ${ }_{8-12}$ and 2 units of Superscript II reverse transcriptase (GIBCO$\mathrm{BRL})$. After a series of incubations $\left(37^{\circ} \mathrm{C}\right.$ for $60 \mathrm{~min}$, $99^{\circ} \mathrm{C}$ for $5 \mathrm{~min}$ and then $0^{\circ} \mathrm{C}$ for $5 \mathrm{~min}$ ), the $\mathrm{RT}$ product was mixed with 1.25 units of Ampli-Taq Gold DNA polymerase (Applied Biosystems, Foster City, CA, USA), and $0.15 \mu \mathrm{M}$ sense and anti-sense primers of iNOS, TNF- $\alpha$, IL- $1 \beta$ and IL- 6 genes in a GeneAmp PCR gold buffer (15 mM Tris-HCl, pH 8.0; $50 \mathrm{mM}$ $\mathrm{KCl}$ ) supplemented with $2 \mathrm{mM} \mathrm{MgCl}_{2}$ and $50 \mu \mathrm{M}$ dNTP. PCR amplification was then performed in sequential cycles at $94^{\circ} \mathrm{C}$ for $30 \mathrm{~s}, 55^{\circ} \mathrm{C}$ for $30 \mathrm{~s}$ and $72^{\circ} \mathrm{C}$ for $30 \mathrm{~s}$, followed by an extension step for $7 \mathrm{~min}$ after the last cycle with a GeneAmp PCR System 9600 (Applied Biosystems). All samples were amplified for 25 cycles, and the PCR samples were electrophoresed on agarose $1.8 \%$ gels (FMC BioProducts, Rockland, ME, USA). Bands in the gel were visualised with ethidium bromide $1 \mu \mathrm{g} / \mathrm{ml}$. The primers used in this study are listed in Table 1 .

\section{Antigenic characterisation of SAA}

Rabbit antisera were prepared by subcutaneous immunisation with SAA and RRA emulsified with Freund's incomplete adjuvant, as described previously [13]. Antigen-specific antibodies were purified from the antisera by Protein A Sepharose (Amersham Pharmacia 
Table 1. Primers for PCR

\begin{tabular}{|c|c|c|c|}
\hline Primers for & & Sequence & $\begin{array}{l}\text { Amplicon size } \\
\text { (bp) }\end{array}$ \\
\hline & & $5^{\prime}$ & \\
\hline \multirow[t]{2}{*}{ iNOS } & $\mathrm{F}$ & CCCTTCCGAAGTTTCTGGCAGC & 494 \\
\hline & $\mathrm{R}$ & GGCTGTCAGAGCCTCGTGGCTTTGG & \\
\hline \multirow[t]{2}{*}{ TNF- $\alpha$} & $\mathrm{F}$ & TCTCATCAGTTCTATTGGCCC & 212 \\
\hline & $\mathrm{R}$ & GGGAGTAGACAAGGTACAAC & \\
\hline \multirow[t]{2}{*}{ IL-1 $\beta$} & $\mathrm{F}$ & TTGACGGACCCCAAAAGATG & 204 \\
\hline & $\mathrm{R}$ & AGAAGGTGCTCATGTCCTCA & \\
\hline \multirow[t]{2}{*}{ IL-6 } & $\mathrm{F}$ & GTTCTCTGGGAAATCGTGGA & 208 \\
\hline & $\mathrm{R}$ & TGTACTCCAGGTAGCTATGG & \\
\hline
\end{tabular}

Bioteck) column chromatography. These antibodies were used in an immunodiffusion test against SAA and RRA in an agar $1 \%$ gel with $0.01 \mathrm{M}$ sodium phosphate buffer ( $\mathrm{pH}$ 7.2). For further antigenic characterisation of SAA, a Western blot analysis was performed with the antibodies, as described previously $[24,25]$. Briefly, SAA (2 $\mu \mathrm{g}$ of protein) was separated by SDS-PAGE $(12.5 \%$ gel). The separated proteins were transferred to a PVDF membrane $(1 \mathrm{~h}$ at $7 \mathrm{~V})$ and immunoblotted with the anti-SAA or anti-RRA antibodies, or both. Immunoreactive proteins were then detected by alkaline phosphatase-conjugated goat antirabbit antibody (Promega). The molecular masses of the bands were calculated by means of molecular size standards.

\section{Statistical analysis}

Data for NO and TNF- $\alpha$ production were analysed by either a multiple comparison method (ANOVA) or an unpaired $t$ test.

\section{Results}

\section{Chemical composition of SAA}

The culture supernate of S. anginosus NCTC 10713 collected by centrifugation and filtration was applied to DEAE-Sephacel and the absorbed fractions were concentrated and applied to size-exclusion HPLC with a TSK gel G4000. Major NO-inducing components were eluted in the earlier fractions (Fig. 1). Therefore, those fractions nos (16-21) concurrent with major hexose and minor protein peaks were pooled and designated as SAA.

Quantitative analyses of SAA and RRA, including hexose (galactose and glucose), de-oxyhexose (rhamnose), hexosamine ( $\mathrm{N}$-acetylglucosamine and $\mathrm{N}$-acetylgalactosamine), protein and phosphorus showed that SAA consisted mainly of carbohydrates, smaller quantities of protein and a trace amount of phosphorus (Table 2). Rhamnose and $\mathrm{N}$-acetylglucosamine were detected in significant amounts in the carbohydrate

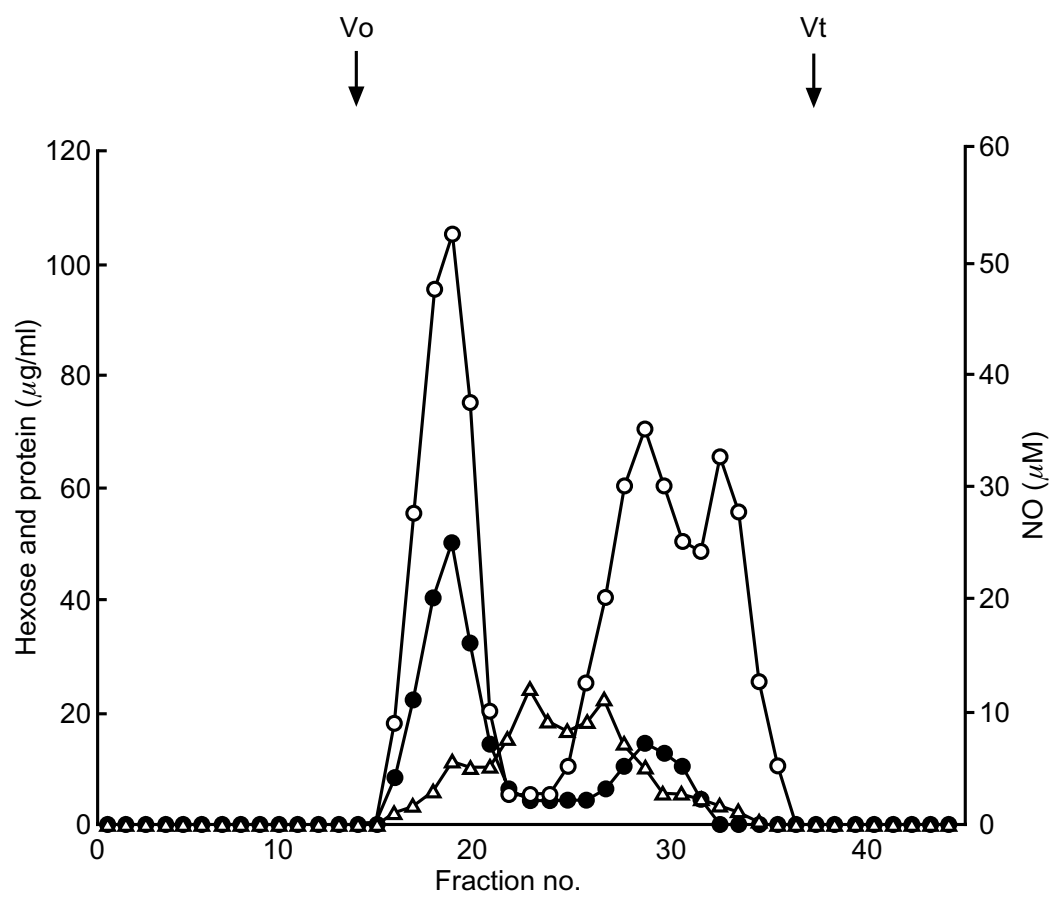

Fig. 1. Size-exclusion HPLC profiles of the NO-inducing activity of $S$. anginosus culture supernate. Sample $(0.5 \mathrm{ml})$ was loaded on to a TSK G4000 SW column equilibrated with $20 \mathrm{mM}$ Tris- $\mathrm{HCl}, \mathrm{pH} 8.0$, elution was at a flow rate of $0.25 \mathrm{ml} / \mathrm{min}$, and a 2-min fraction was collected. Arrows indicate the elution position of the void volume (Vo) and total column volume $(\mathrm{Vt})$. Symbols indicate content of hexose $(\mathrm{O})$, protein $(\triangle)$ and NO 
Table 2. Chemical composition of SAA and RRA $(\mu \mathrm{g} / \mathrm{ml})$

\begin{tabular}{lcc}
\hline Components & SAA & RRA \\
\hline Rhamnose & 180 & 200 \\
Galactose & 32 & 24 \\
Glucose & 44 & 28 \\
$N$-Acetylglucosamine & 100 & 70 \\
$N$-Acetylgalactosamine & 10 & 8 \\
Phosphorus & 1.1 & 2.4 \\
Protein & 44 & 74 \\
\hline
\end{tabular}

component of SAA. The chemical composition of SAA was similar to that of RRA, although the contents were slightly different.

\section{SAA-induced NO production}

When PEC from C57BL/6N mice were cultured in the presence of SAA as well as LPS or LTA, NO synthesis was markedly induced, whereas no significant production was observed after stimulation with RRA (Table $3)$. SAA induced NO synthesis in a dose-dependent manner $(0.1-10 \mu \mathrm{g} / \mathrm{ml})$, reaching a plateau with $10-30 \mu \mathrm{g} / \mathrm{ml}$. Treatment of SAA with polymyxin B did not alter its NO-inducing activity, whereas the activity of LPS was abolished with polymyxin B $10 \mu \mathrm{g} / \mathrm{ml}$. The SAA-induced NO synthesis was abolished by heat $\left(121^{\circ} \mathrm{C}, 20 \mathrm{~min}\right)$ (Fig. 2). Furthermore, RT-PCR analysis indicated that SAA induced the accumulation of iNOS mRNA, whereas this accumulation was not detected after stimulation with RRA (Fig. $3)$.
Table 3. NO production after stimulation of mutine PEC with SAA, RRA, LPS and LTA at $37^{\circ} \mathrm{C}$ for $24 \mathrm{~h}$

\begin{tabular}{|c|c|c|}
\hline Stimulant & $\begin{array}{l}\text { Amount added } \\
(\mu \mathrm{g} / \mathrm{ml})\end{array}$ & $\begin{array}{c}\text { Mean (SEM) } \\
(\mathrm{mM}) \mathrm{NO}^{*}\end{array}$ \\
\hline SAA & $\begin{array}{l}0.1 \\
1.0 \\
10 \\
30 \\
10+\text { PMB }\end{array}$ & $\begin{array}{r}3.7(1.7) \\
17.7(1.7) \\
52.6(2.0) \\
54.2(4.8) \\
49.0(4.2)\end{array}$ \\
\hline RRA & $\begin{array}{l}0.1 \\
1.0 \\
10 \\
30 \\
10+\mathrm{PMB}\end{array}$ & $\begin{array}{r}4.3(1.7) \\
4.5(1.3) \\
7.3(2.2) \\
11.7(3.0) \\
6.0(1.1)\end{array}$ \\
\hline LPS & $\begin{array}{l}0.1 \\
1.0 \\
10 \\
30 \\
10+\text { PMB }\end{array}$ & $\begin{aligned} 37.5 & (6.4) \\
48.2 & (7.2) \\
54.7 & (12.0) \\
59.7 & (6.8) \\
8.5 & (1.9)\end{aligned}$ \\
\hline LTA & $\begin{array}{l}0.1 \\
1.0 \\
10 \\
30 \\
10+\mathrm{PMB}\end{array}$ & $\begin{aligned} 4.2 & (1.7) \\
24.5 & (6.6) \\
46.0 & (2.8) \\
40.5 & (4.1) \\
43.0 & (2.4)\end{aligned}$ \\
\hline
\end{tabular}

*Polymyxin B (PMB) was added to the reaction mixtures at $10 \mu \mathrm{g} / \mathrm{ml}$. Data are the means (SEM) of NO concentration of four different experiments.

\section{SAA-induced cytokine production}

To assess SAA-induced cytokine production by PEC, the study examined TNF- $\alpha$ production by ELISA and TNF- $\alpha$, IL- $1 \beta$ and IL- 6 mRNA expression by means of RT-PCR. As shown in Fig. 4, SAA $10 \mu \mathrm{g} / \mathrm{ml}$ and RRA each stimulated PEC to produce significant amounts of TNF- $\alpha$ in the culture supernate. Moreover, heated SAA also induced the production of TNF- $\alpha$. RT-PCR revealed that SAA could induce accumulation of TNF- $\alpha$,

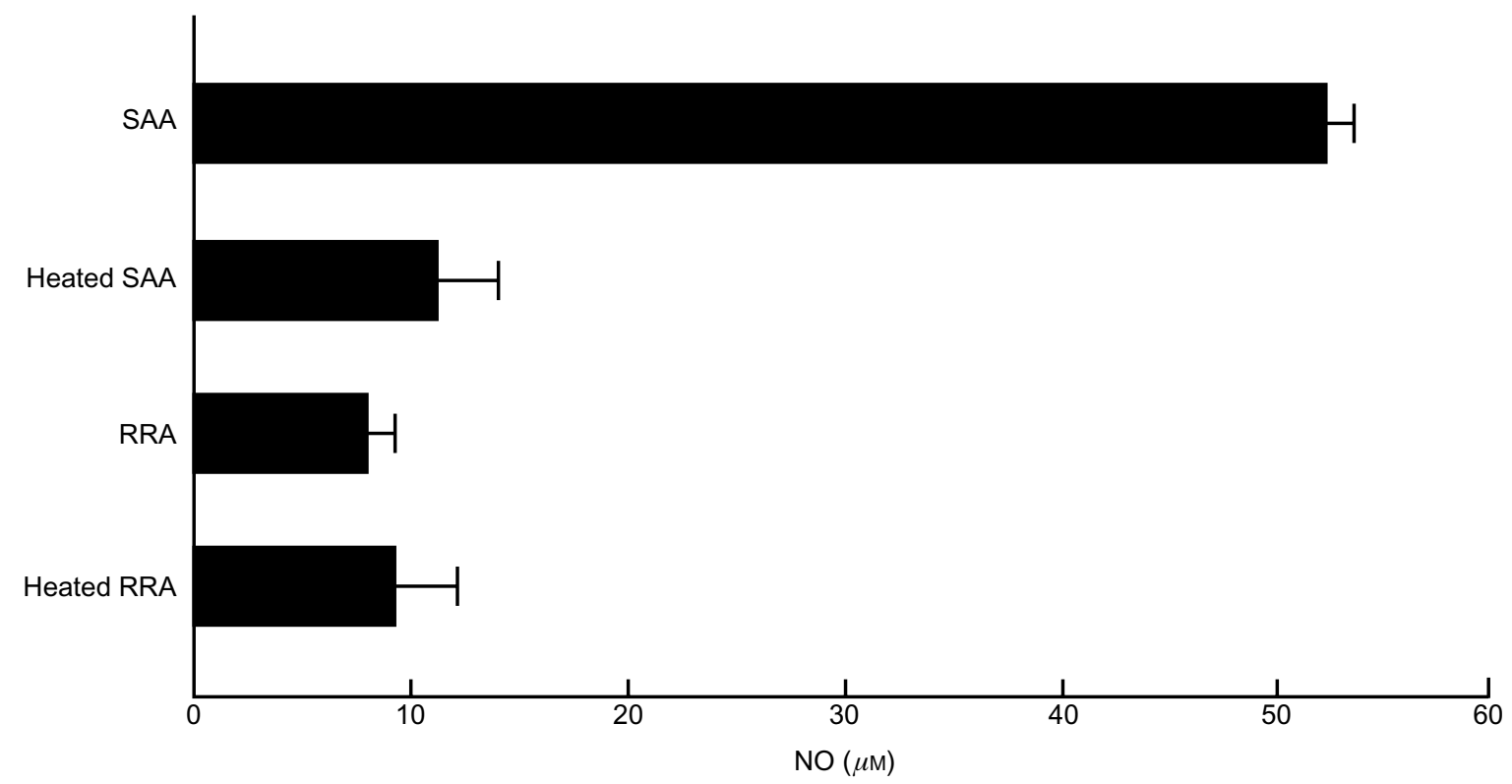

Fig. 2. Effect of heat on NO-inducing activity of SAA. Murine PEC were incubated at $37^{\circ} \mathrm{C}$ with SAA, RRA $(10 \mu \mathrm{g} / \mathrm{ml})$, heated $\left(121^{\circ} \mathrm{C}\right.$ for $\left.20 \mathrm{~min}\right) \mathrm{SAA}$ and heated RRA. After $24 \mathrm{~h}$, NO in the culture supernates was measured by the Griess method. Data are expressed as the means (SEM) of NO concentration of four different experiments. 


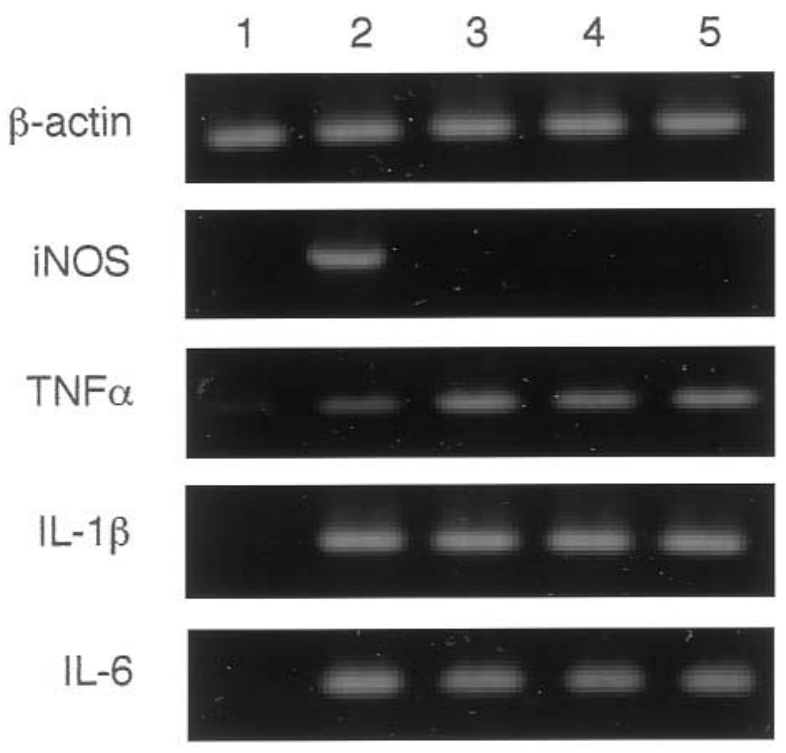

Fig. 3. Induction of iNOS, TNF- $\alpha, \quad$ IL- $1 \beta$ and IL-6 mRNA in murine PEC stimulated with SAA, RRA, heated SAA and heated RRA (each $10 \mu \mathrm{g} / \mathrm{ml}$ ) at $37^{\circ} \mathrm{C}$. After $3 \mathrm{~h}$, total RNA was prepared, and $\beta$-actin, iNOS, TNF- $\alpha$, IL- $1 \beta$ and IL- 6 mRNA were amplified by RTPCR. The PCR products were analysed in an agarose $1.8 \%$ gel. Lane 1, medium; 2, SAA; 3, heated SAA; 4, RRA; 5, heated RRA.

IL- $1 \beta$ and IL-6 mRNA as well as iNOS mRNA (Fig. 3 ). In contrast, stimulation with RRA and heated SAA resulted in a definitive accumulation of TNF- $\alpha$, IL- $1 \beta$ and IL-6, but not iNOS, mRNA, in PEC (Fig. 3).

\section{Antigenic characterisation of SAA}

In an immunodiffusion test, anti-SAA antibodies formed a single precipitin band with SAA but not with RRA (Fig. 5A). On the other hand, anti-RRA antibodies formed a line of identity with both RRA and SAA (Fig. 5B). SAA formed crossing lines in reactions with anti-SAA and anti-RRA antibodies (Fig. 5C), indicating that it might possess two different antigenic components - one that reacts specifically with antiSAA antibodies and the other with anti-RRA antibodies.

To characterise the antigenic component that reacted specifically with anti-SAA antibodies, an immunoblot analysis with anti-SAA antibodies was performed. Although both SAA and RRA contain several protein components, the $43 \mathrm{kDa}$-protein band (p43) in SAA reacted with anti-SAA antibodies (Fig. 6), although not with anti-RRA antibodies (data not shown). Furthermore, RRA showed no obvious band in the immunoblot analysis with anti-SAA antibodies.

\section{Discussion}

SAA, a novel antigen purified from the culture supernate of $S$. anginosus NCTC 10713, induced NO synthesis in PEC from $\mathrm{C} 57 \mathrm{BL} / 6 \mathrm{~N}$ mice. Chemical analysis revealed that SAA consists mainly of carbohydrates, such as rhamnose and $N$-acetylglucosamine, and smaller quantities of protein. Its composition was essentially similar to that of RRA (Table 2), as well as to that of the carbohydrate antigen of the serotype $\mathrm{k} /$ Lancefield group $\mathrm{G}$ extracted by autoclaving whole cells of $S$. anginosus K-214-2K [26]. These results strongly suggest that the composition of SAA could be closely related to serotype carbohydrate antigen(s), but not to that of LTA or RGPs.

When PEC were cultured in the presence of SAA, NO

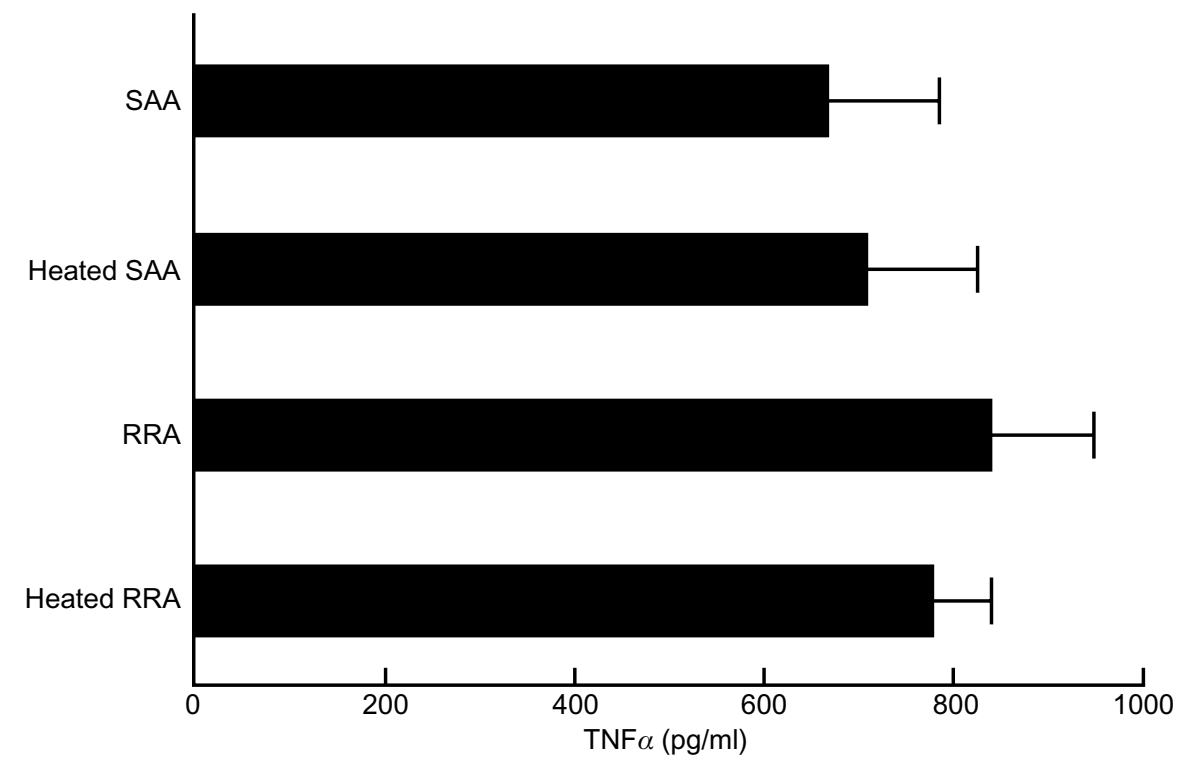

Fig. 4. TNF- $\alpha$ production from C57BL/6 murine PEC stimulated with SAA, RRA, heated SAA and heated RRA (each $10 \mu \mathrm{g} / \mathrm{ml})$ at $37^{\circ} \mathrm{C}$ for $24 \mathrm{~h}$. TNF- $\alpha$ content in the culture supernates was measured by ELISA. Data are expressed as the mean (SEM) TNF- $\alpha$ concentration of four different experiments. The TNF- $\alpha$ content of the non-stimulated control was $<50 \mathrm{pg} / \mathrm{ml}$. 
A

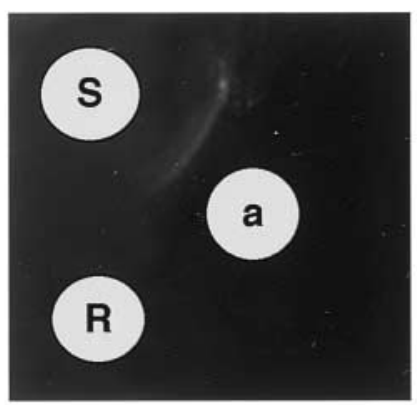

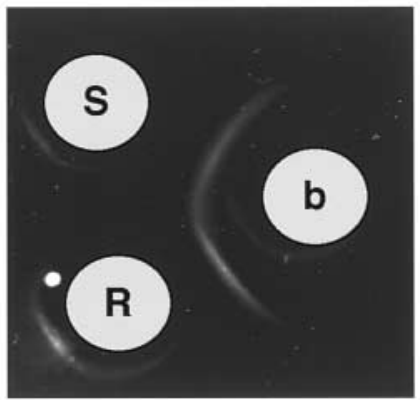

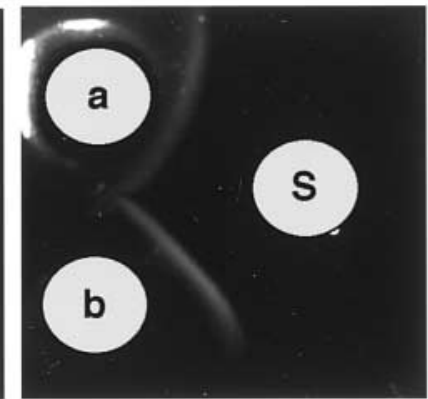

Fig. 5. Immunodiffusion: antigens and antibodies were allowed to react in an agar $1 \%$ gel in $0.01 \mathrm{M}$ sodium phosphate buffer (pH 7.2). a, anti-SAA antibodies; b, anti-RRA antibodies; S, SAA ( $5 \mu \mathrm{g} / \mathrm{ml})$; R, RRA $(5 \mu \mathrm{g} / \mathrm{ml})$.

A

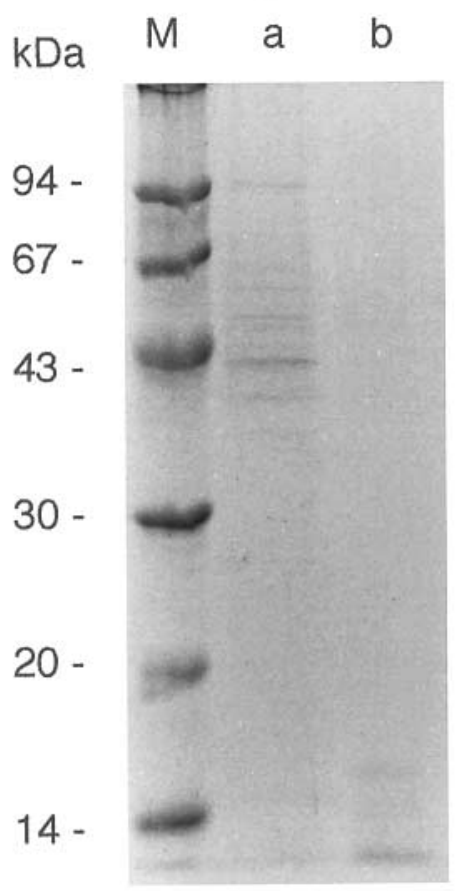

B
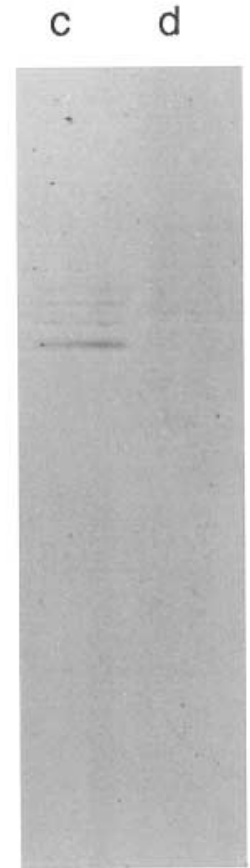

Fig. 6. SDS-PAGE (polyacrylamide $12.5 \%$ gel) of SAA and RRA processed by Coomassie staining (A) and developed by immunoblotting (B). Lanes a and $\mathbf{c}$, SAA $(2 \mu \mathrm{g}) ; \mathbf{b}$ and $\mathbf{d}$, RRA $(2 \mu \mathrm{g})$.

synthesis was induced (Table 3). RT-PCR also revealed that SAA could induce accumulation of iNOS mRNA (Fig. 3). In contrast, RRA could not induce NO synthesis or accumulation of iNOS mRNA, although production and mRNA accumulation of TNF- $\alpha$, IL- $1 \beta$ and IL-6 were observed, which was the same as with SAA (Fig. 3). An immunodiffusion assay indicated that SAA could possess two different antigenic components - one that reacts specifically with anti-SAA antibodies, and another that has an identity similar to that of RRA (Fig. 5). Moreover, the 43-kDa protein band reacted with anti-SAA antibodies, but not with anti-RRA antibodies, in an immunoblot analysis (Fig. 6). Therefore, it is most likely that the protein molecule (p43) of SAA in reaction with anti-SAA antibodies could exclusively induce NO synthesis, and that the carbo-

hydrate component(s) closely related to the serotype carbohydrate antigen(s) of $S$. anginosus could induce cytokine production. In fact, SAA-induced NO synthesis was abolished by heat, which is a condition needed for the preparation of RRA as well as the carbohydrate antigen of the serotype k/Lancefield group G (Fig. 3). This finding makes it unlikely that SAA-induced NO synthesis is related to contamination by RGPs (rhamnose glucose polymers) or LTA, or both, in SAA, as these streptococcal antigens are heat-stable. Furthermore, putative contamination of LPS was also ruled out by the finding that treatment of SAA with polymyxin B did not alter its NO-inducing activity (Table 3 ).

SAA stimulated murine PEC to induce NO production regardless of the mouse strains used, as with LTA and RGPs (data not shown). However, the precise mechanism of NO production from PEC after stimulation with bacterial components, including LTA and RGPs, has not been fully addressed. English et al. [11] indicated that streptococcal LTA provoked NO production from murine macrophages only in the presence of recombinant interferon (IFN)- $\gamma$, while Drapier et al. [27] reported that IFN- $\gamma$ and TNF- $\alpha$ are synergically to induce nitrite synthesis in murine macrophages after stimulation with bacterial antigens. Furthermore, Mond et al. [28] suggested that T-independent type 2 antigens, such as carbohydrate antigens, could activate immunocompetent cells by cross-linking multiple cell surface molecules, thereby inducing signal transduction events that result in cellular activation and differentiation. In fact, a previous report found that a serotype carbohydrate antigen from $S$. mutans, a T-independent type 2 antigen, induced murine $\mathrm{B}$ cell responses [6] and that a cell wall carbohydrate antigen from Actinomyces viscosus induced cytokine production from murine macrophages [21]. Thus, it is possible that the carbohydrate molecule (or protein molecule, or both) in SAA could stimulate the lymphoid cell populations in $\mathrm{PEC}$, resulting in the production of cytokine(s), which is required for NO production from the macrophages in PEC by stimulation with the protein molecule in SAA. This hypothesis is supported by the observation that SAA-induced NO synthesis, but not cytokine production, was sensitive to heat. 
Taken together, the present results clearly indicate that SAA, a novel cell surface antigen of S. anginosus, has a potential to interact with host cells to induce NO synthesis as well as produce inflammatory cytokines in murine PEC. These findings may facilitate further understanding of the aetiological mechanisms in some oral and systemic inflammatory diseases caused by $S$. anginosus infection, although further studies are clearly required.

\section{References}

1. Ruoff KL. Streptococcus anginosus ("Streptococcus milleri"): the unrecognized pathogen. Clin Microbiol Rev 1988; 1: $102-108$.

2. Gossling J. Occurrence and pathogenicity of the Streptococcus milleri group. Rev Infect Dis 1988; 10: 257-285.

3. Whitworth JM. Lancefield group F and related streptococci. $J$ Med Microbiol 1990; 33: 135-151.

4. Willcox MDP. Potential pathogenic properties of members of the "Streptococcus milleri" group in relation to the production of endocarditis and abscesses. J Med Microbiol 1995; 43: $405-410$.

5. Hamada S, Michalek SM, Kiyono H, Menaker L, McGhee JR (eds) Molecular microbiology and immunobiology of Streptococcus mutans. Amsterdam, Elsévier Science Publishers. 1986.

6. Kimura S, Kiyono H, Beagley $\mathrm{KW}$ et al. Streptococcal serotype carbohydrate represents a novel class of type 2 antigen which is T-independent. $J$ Immunol 1987; 138 4387-4394.

7. Bhakdi S, Klonisch T, Nuber P, Fischer W. Stimulation of monokine production by lipoteichoic acids. Infect Immun 1991; 59: 4614-4620.

8. Keller R, Fischer W, Keist R, Bassetti S. Macrophage response to bacteria: induction of marked secretory and cellular activities by lipoteichoic acids. Infect Immun 1992; 60: 3664-3672.

9. Sasaki M, Ohara-Nemoto Y, Tajika S, Kaneko M. Induction of inflammatory cytokine and cyclooxygenase-2 mRNA expression by secreted substances from oral streptococci. Dent $J$ Iwate Med Univ 1995; 20: 284-290.

10. Martin V, Kleschyov AL, Klein J-P, Beretz A. Induction of nitric oxide production by polyosides from the cell walls of Streptococcus mutans OMZ 175, a gram-positive bacterium, in the rat aorta. Infect Immun 1997; 65: 2074-2079.

11. English BK, Patrick CC, Orlicek SL, McCordic R, Shenep JL. Lipoteichoic acid from viridans streptococci induces the production of tumour necrosis factor and nitric oxide by murine macrophages. J Infect Dis 1996; 174: 1348-1351.

12. Stoclet J-C, Fleming I, Gray G et al. Nitric oxide and endotoxemia. Circulation 1993; 87 (suppl V): V-77-V-80.

13. Hamada S, Okahashi N, Kimura S et al. Novel antigens of oral Actinomyces species prepared from a cell wall enzyme lysate. Jpn J Med Sci Biol 1982; 35: 171-181.

14. Dubois M, Gilles KA, Hamilton JK, Rebers PA, Smith F. Colorimetric method for determination of sugars and related substances. Anal Chem 1956; 28: 350-356.

15. Dische Z, Shettles LB. A specific color reaction of methylpentoses and a spectrophotometric micromethod for their determination. J Biol Chem 1948; 175: 595-603.

16. Dische Z. Spectrophotometric method for the determination of free pentose and pentose in nucleotides. J Biol Chem 1949; 181: 379-392.

17. Dische Z, Shettles LB, Osnos M. New specific color reactions of hexoses and spectrophotometric micromethods for their determination. Arch Biochem 1949; 22: 169-184.

18. Ludowieg J, Benmaman JD. Colorimetric differentiation of hexosamines. Anal Biochem 1967; 19: 80-88.

19. Bradford MM. A rapid and sensitive method for the quantitation of microgram quantities of protein utilizing the principle of protein-dye binding. Anal Biochem 1976; 72: 248-254.

20. Chen PS, Toribara TY, Warner H. Microdetermination of phosphorus. Anal Chem 1956; 28: 1756-1758.

21. Takada H, Kimura S, Hamada S. Induction of inflammatory cytokines by a soluble moiety prepared from an enzyme lysate of Actinomyces viscosus cell walls. J Med Microbiol 1993; 38: $395-400$.

22. Eze MO, Yuan L, Crawford RM et al. Effects of opsonization and gamma interferon on growth of Brucella melitensis $16 \mathrm{M}$ in mouse peritoneal macrophages in vitro. Infect Immun 2000; 68: $257-263$.

23. Kimura S, Tamamura T, Nakagawa I, Koga T, Fujiwara T, Hamada S. CD14-dependent and independent pathways in lipopolysaccharide-induced activation of a murine B-cell line, CH12.LX. Scand J Immunol 2000; 51: 392-399.

24. Kimura S, Koga $\mathrm{T}$, Fujiwara $\mathrm{T}$ et al. Tyrosine protein phosphorylation in murine B lymphocytes by stimulation with lipopolysaccharide from Porphyromonas gingivalis. FEMS Microbiol Lett 1995; 130: 1-6.

25. Sasaki M, Ohara-Nemoto Y, Tajika S et al. Purification and characterization of a glutamic acid-specific protease from Staphylococcus epidermidis. Jpn J Oral Biol 1998; 40: $542-548$.

26. Kitada K, Inoue M. Immunochemical characterization of the carbohydrate antigens of serotype $\mathrm{k}$ and Lancefield group $\mathrm{G}$ "Streptococcus milleri". Oral Microbiol Immunol 1996; 11: 22-28.

27. Drapier J-C, Wietzerbin J, Hibbs JB. Interferon- $\gamma$ and tumour necrosis factor induce the $\mathrm{L}$-arginine-dependent cytotoxic effector mechanism in murine macrophages. Eur $J$ Immunol 1988; 18: 1587-1592.

28. Mond JJ, Lees A, Snapper CM. T cell-independent antigens type 2. Annu Rev Immunol 1995; 13: 655-692. 